\title{
Pandangan Dan Perjuangan Ki Hadjar Dewantara Dalam Memajukan Pendidikan Nasional
}

\author{
Zuriatin $^{1, *}$, Nurhasanah ${ }^{2}$, Nurlaila $^{3}$ \\ ${ }^{1}$ STKIP Taman Siswa Bima \\ ${ }^{2}$ STKIP Bima \\ ${ }^{3}$ STISIP Mbojo Bima \\ *atinamin57@gmail.com
}

Artikel Info

Tanggal Publikasi

2021-06-30

$\underline{\text { Kata Kunci }}$

Pandangan

Perjuangan

Ki Hadjar

Dewantara

Pendidikan

\section{Abstrak}

Ki Hadjar Dewantara merupakan tokoh pembaharu dalam dunia pendidikan nasional pahlawan nasional ini di kenal sebagai bapak pendidikan nasional yang memperjuangkan dan mengangkat martabat bangsa melalui bidang pendidikan. Citacita Ki hadjar Dewantara yaitu menciptakan pendidikan yang sesuai dengan adat istiadat bangsa Indonesia. Ki Hadjar Dewantara bertekad untuk meluaskan semangat tentang pendidikan kepada generasi muda. Dalam pandangan beliau upaya untuk mendidik kaum muda merupakan syarat utama dalam membebaskan diri dari jeratan penjajah. Pendidikan yang mendasarkan kebudayaan nasional dapat menghindarkan dari kebodohan. Untuk mewujudkan cita-cita dan pandangan tersebut Tanggal 3 Juli 1922 babak baru perjuangan Ki Hadjar Dewantara dalam bidang pendidikan di mulai yaitu dengan mendirikan Taman Siswa yang mula-mula bernama " National Onderwijs Instituut Taman Siswa” yang pertama di Jogjakarta, sekolah ini kelak di ubah menjadi "Perguruan Kebangsaan Taman Siswa"

\section{PENDAHULUAN}

Pendidikan adalah segala daya upaya dan semua usaha untuk membuat masyarakat dapat mengembangkan potensi manusia agar memiliki kekuatan spiritual keagamaan, pengendalian diri, berkepribadian, memiliki kecerdasan, berakhlak mulia, serta memiliki keterampilan yang diperlukan sebagai anggota masyarakat dan warga negara. Di samping itu pendidikan merupakan usaha untuk membentuk manusia yang utuh lahir dan batin cerdas, sehat, dan berbudi pekerti luhur. Pendidikan mampu membentuk kepribadian melalui pendidikan lingkungan yang bisa dipelajari baik secara sengaja maupun tidak. Pendidikan juga mampu membentuk manusia itu memiliki disiplin, pantang menyerah, tidak sombong, menghargai orang lain, bertaqwa, dan kreatif, serta mandiri.

Manusia tidak bisa lepas dari pendidikan. Pendidikan merupakan salah satu sektor penting dalam pembangunan di setiap negara. Menurut Undang-Undang No. 20 Tahun 2003 tentang Sisdiknas dalam pasal 1 disebutkan bahwa pendidikan merupakan usaha sadar dan terencana untuk mewujudkan suasana belajar dan proses pembelajaran agar peserta didik secara aktif mengembangkan potensi dirinya untuk memiliki kekuatan spiritual keagamaan, pengendalian diri, kepribadian, kecerdasan, akhlak mulia, serta keterampilan yang diperlukan dirinya, masyarakat, mengembangkan segala potensi yang dimiliki peserta didik melalui proses pembelajaran. Dalam pasal 4 dijelaskan bahwa peserta didik adalah anggota masyarakat yang berusaha mengembangkan potensi diri melalui proses pembelajaran yang tersedia pada jalur, jenjang, dan jenis pendidikan tertentu. Dengan demikian pendidikan adalah segala daya upaya dan semua usaha untuk membuat masyarakat dapat mengembangkan potensi peserta didik agar memiliki kekuatan spiritual keagamaan, pengendalian diri, berkepribadian, memiliki kecerdasan, berakhlak mulia, serta memiliki keterampilan yang diperlukan sebagai anggota masyarakat dan warga negara. 
Tujuan pendidikan itu juga ditanamkan sejak manusia masih dalam kandungan, lahir, hingga dewasa yang sesuai dengan perkembangan dirinya. Ketika masih kecil pun pendidikan sudah dituangkan dalam UU 20 Sisdiknas 2003, yaitu disebutkan bahwa pada pendidikan anak usia dini bertujuan untuk mengembangkan kepribadian dan potensi diri sesuai dengan tahap perkembangan peserta didik (Depdiknas 2003: 11). Dengan demikian tujuan pendidikan juga mengalami perubahan menyesuaikan dengan perkembangan manusia. Oleh karena pendidikan dialami sejak manusia lahir hingga dewasa, maka tujuan pendidikan juga merupaka suatu proses. Proses "memanusiakan dirinya sebagai manusia” merupakan makna yang hakiki di dalam pendidikan. Keberhasilan pendidikan merupakan "cita-cita pendidikan hidup di dunia" (Dalam agama ditegaskan juga bahwa cita-cita "hidup" manusia adalah di akherat). Akan tetapi tidak selamanya manusia menuai hasil dari proses yang diupayakan tersebut. Oleh karena itu, kadang proses itu berhasil atau kadang pun tidak. Jadi dengan demikian dapat dikatakan bahwa "keberhasilan" dari proses pendidikan secara makro tersebut merupakan tujuan. Keberhasilan itu jug dipengaruhi oleh beberapa faktor. Hal ini mengingat bahwa pendidikan itu ada tiga pilar yaitu pendidikan keluarga, pendidikan sekolah, dan pendidikan masyarakat. Dalam pembentukan dan tujuan pendidikan yang berkaitan dengan pembentukan watak, maka faktor keluarga sangat penting. Faktor orang tua sangat berpengaruh pada pendidikan manusia sebagai peserta didik. Kesadaran orang tua makin meningkat mengenai pentingnya pendidikan sebagai persiapan awal untuk membantu pencapaian keberhasilan pendidikan selanjutnya. Persiapan awal tersebut menyangkut pencapaian perkembangan sehat secara mental, emosi, dan sosial. Namun orang tua juga tidak sama. Seperti yag dikemukakan berikut ini bahwa kadang orang tua belum memiliki pengetahuan dan keterampilan yang memadai untuk membantu kesiapan anak untuk mengikuti pendidikan selanjutnya atau perkembangan sehat mental, emosi, sosial, dan fisik anak (Sodiq A. Kuntoro, 1988: 1).

Gambaran ideal pendidikan seperti yang di paparkan di atas sayangnya di masa lalu tidak dapat di miliki oleh semua kalangan masyarakat pendidikan di batasi dan di peruntukan bagi bangsa eropa yang menguasai nusantara dan para bangsawan. rakyat biasa tidak di perkenankan sama sekali untuk mengenyam pendidikan hal ini terus berlanjut dalam jangka waktu yang lama hingga muncul tokohtokoh pembaharu yang memperjuangkan kemerdekaan dan kebebasan terutama dalam bidang pendidikan salah satu tokoh hebat yang berhasil meletakan dasar-dasar pendidikan rakyat yang nantinya menjadi dasar pendidikan nasional yaitu Bendara Raden Tumenggung Harya Suwardi Soerjaningrat yang lebih dikenal dengan nama Ki Hadjar Dewantara. Beliau merupakan bapak pendidikan nasional yang gigih berjuang dalam membangun pendidikan bagi masyarakat Indonesia. Dalam penelitian ini kita akan membahas bagaimana "Pandangan dan perjuangan Ki Hadjar Dewantara dalam memajukan pendidikan nasional"

\section{METODE PENELITIAN}

Metode penelitian ini adalah kajian pustaka (library research). Kajian pustaka merupakan teknik penelitian dengan cara melakukan penelusuran-penelusuran tentang konsep-konsep pemikiran Ki Hajar Dewantara. Dalam mempermudah mendapatkan hasil dari pada kajian pustaka terhadap penelitian ini, yakni peneliti menggunakan teknik membaca dan menganalisis segala tulisan Ki Hajar Dewantara yang ada tentang pendidikan, politik, maupun kebudayaan. Sumber data yang di gunakan terdiri dari dua yaitu sumber primer dan sumber sekunder. Sumber data dibedakan menjadi $2: 1$ ). Sumber primer, meliputi karya yang ditulis oleh Ki Hajar Dewantara sendiri. 2). Sumber sekunder, meliputi karya tentang Ki Hajar Dewantara yang ditulis orang lain. Dalam menganalisis data yang telah terkumpul, peneliti akan menggunakan content analisys (Muhadjir, 1991: 183) Analisis ini dilakukan untuk menjelaskan isi sebuah buku yang menggambarkan situasi penulis dan masyarakat pada saat buku tersebut ditulis. 


\section{HASIL DAN PEMBAHASAN}

\section{Biografi Singkat Ki Hadjar Dewantara}

Ki Hadjar Dewantar memiliki nama kecil Raden Mas Soewardi Soerjaningrat, kemudian pada tahun 1922 beliau mengganti namanya menjadi Ki Hadjar Dewantara seperti yang kita kenal sekarang. Beliau dilahirkan di Yogyakarta pada tanggal 2 Mei 1889 dari keluarga bangsawan Yogyakarta beliau merupakan cucu Pakualam III. Ayah Ki Hadjar dewantara bernama K.P.H. Suryaningrat dan Ibunya bernama Raden Ayu Sandiyah. Pada masa lingkungan hidup Ki Hajar Dewantara kecil sangat mempengaruhi jiwanya yang sangat peka dan tertarik terhadap kesenian dan nilai-nilai kultur maupun keagamaan. Setelah mengganti namanya menjadi Ki Hajar Dewantara, beliau dapat leluasa bergaul dengan rakyat. Sehingga dengan demikian perjuangan beliay menjadi lebih mudah diterima pada masa itu. Ki Hadjar Dewantaara dan R.A. Soetartinah melangsungkan "Nikah Gantung" tanggal 4 November 1907. Akhir Agustus 1913 tepatnya beberapa hari sebelum berangkat ke tempat pengasingan di negeri Belanda. Pernikahannya diresmikan secara sederhana di Puri Suryaningratan Yogyakarta. Ki Hadjar Dewantara meninggal dunia pada usia 69 tahun pada tanggal 26 Apri 1959, di rumahnya Mujamuju Yogyakarta. Pada Tanggal 28 November 1959, Ki Hadjar Dewantara ditetapkan sebagai "Pahlawan Nasional”. Tanggal 16 Desember 1959, pemerintah menetapkan tanggal 2 Mei sebagai "Hari Pendidikan Nasional" yang merupakan tanggal lahir Ki Hadjar Dewantara berdasarkan keputusan Presiden RI Nomor: 316 tahun 1959. Semasa hidupnya, Ki Hadjar Dewantara sangat kreatif, dinamis, jujur, sederhana, konsisten, dan berani. Beliau memiliki wawasan yang luas dan tidak gentar berjuang untuk bangsa hingga akhir hayatnya. Perjuangan beliau dilandasi dengan rasa ikhlas, sertai pengabdian dan pengorbanan yang tinggi dalam usaha merebut kemerdekaan bangsanya. (Mariyah dkk, 2019: 1517)

Ki Hajar Dewantara adalah Bapak Pendidikan Nasional. Hal itu karena beliau merupakan seorang tokoh yang tanpa jasa memerdekakan Indonesia. Pengabdian yang ia berikan begitu besar terhadap bangsanya. Banyaknya karya yang membuat Indonesia menjadi bangga pun sering ia lakukan. Bahkan saking begitu banyak membuat Indonesia bangga, tanggal lahir Ki Hajar Dewantara menjadi hari Pendidikan Nasional. Hari yang dikenal seluruh warga Indonesia. Hari seseorang yang dilahirkan untuk memerdekakan pendidikan di Indonesia. Dengan kepintaran, kebijaksanaan, tekun dan berani memerdekakan hak dari orang lain dan bangsanya melawan penjajah. Ki Hajar Dewantara berasal dari lingkungan keluarga Keraton Yogyakarta. Ki Hajar Dewantara lahir di Yogyakarta, 2 Mei 1889 meninggal di usia 69 tahun di Yogyakarta, 26 April 1959. Dengan nama kecil Raden Mas Soewardi Soerjaningrat (EYD: Suwardi Suryaningrat) setelah itu sejak 1922 menjadi Ki Hadjar Dewantara (EYD: Ki Hajar Dewantara, beberapa menuliskan bunyi bahasa Jawanya dengan Ki Hajar Dewantoro). Beliau merupakan aktivis pergerakan kemerdekaan Indonesia, kolumnis, politisi, dan pelopor pendidikan bagi kaum pribumi Indonesia saat zaman penjajahan Belanda. ELS merupakan sekolah dasar di Eropa, Belanda yang menjadi lulusan Ki Hajar Dewantara. Kemudian sempat melanjut ke STOVIA (Sekolah Dokter Bumiputera), tapi tidak sampai tamat karena sakit. Kemudian ia bekerja sebagai penulis dan wartawan di beberapa surat kabar, antara lain, Sediotomo, Midden Java, De Expres, Oetoesan Hindia, Kaoem Moeda, Tjahaja Timoer, dan Poesara. Pada masanya, ia tergolong penulis handal. Tulisan-tulisannya komunikatif dan tajam dengan semangat antikolonial. Banyak karya-karya yang dimiliki beliau. Berbagai macam cara yang dilakukan Ki Hajar dewantara demi memperjuangkan kemerdekaan pendidikan Indonesia. Salah satunya dengan seringnya mengubah namanya sediri. Hal tersebut dimasudkan untuk menunjukkan perubahan sikapnya dalam melaksanakan pendidikan yaitu dari satria pinandita ke pinandita satria yaitu dari pahlawan yang berwatak guru spiritual ke guru spiritual yang berjiwa ksatria, yang mempersiapkan diri dan peserta didik untuk melindungi bangsa dan negara. (Sugiata dkk. 2019; 127) 


\section{Pandangan Ki Hadjar Dewantara Tentang Pendidikan}

Ki Hadjar Dewantara bertekad untuk meluaskan semangat tentang pendidikan kepada generasi muda. Dalam pandangan beliau upaya untuk mendidik kaum muda merupakan syarat utama dalam membebaskan diri dari jeratan penjajah. Pendidikan yang mendasarkan kebudayaan nasional dapat menghindarkan dari kebodohan. Pendidikan yang ada pada masa kolonial tidak mencerdaskan, melainkan mendidik manusia untuk tergantung pada nasib dan bersikap pasif. Keinginan untuk merdeka harus dimulai dengan mempersiapkan kaum bumi putra yang bebas, mandiri, dan pekerja keras. Sehingga generasi muda harus dipersiapkan agar kelak menjadi bangsa yang mandiiri, sadar akan kemerdekaan, sehingga kemerdekaan itu dimiliki oleh orang yang terdidik dan memiliki jiwa yang merdeka (Marihandono, 2017). Bagi Ki Hadjar Dewantara, pendidikan itu memberikan dorongan terhadap perkembangan siswa didik, yakni pendidikan mengajarkan untuk mencapai suatu perubahan dan dapat bermanfaat di lingkungan masyarakat. Dalam hal ini, siswa didik diharapkan mampu memberikan manfaat untuk lingkungan keluarga, lingkungan tempat tinggal ataupun untuk masyarakat luas. Selain itu, dengan pendidikan juga diharapkan memberikan peningkatan rasa percaya diri, mengembangkan potensi yang ada dalam diri karena selama ini pendidikan hanya dianggap sebagai sarana untuk mengembangkan aspek kecerdasan, namun tidak diimbangi dengan kecerdasan dalam bertingkah laku maupun dengan ketrampilan. Disisi lain, guru sebagai tokoh sentral dalam dunia pendidikan juga diharapkan mengutamakan murid di atas kepentingan pribadi. Menurut Ki Hadjar Dewantara, seorang guru juga diharapkan mampu mengembangkan metode yang sesuai dengan sistem pengajaran dan pendidikan, yaitu metode among, yakni metode pengajaran dan pendidikan yang berdasarkan pola asih, asah, dan asuh. Guru diharapkan memiliki keterampilan dalam mengajar, memiliki keunggulan dalam berelasi dengan peserta didik maupun dengan anggota komunitas yang ada di sekolah, dan guru juga harus mampu berkomunikasi dengan orang tua murid dan memiliki sikap profesionalitas dalam menjalankan tugasnya. Seorang pendidik juga diharapkan mampu mendidik peserta didik dengan memegang semboyan dari Ki Hadjar Dewantara yakni, ing ngarsa sung tuladha (dimuka memberi contoh), ing madya mangun karsa (di tengah membangun citacita), tut wuri handayani (mengikuti dan mendukungnya) (Haidar Musyafa, 2015). Hal yang paling utama dalam mendidik, yakni adanya pemahaman yang sama antara guru dan pendidik, sehingga mendidik bersifat "humanisasi", yaitu mendidik merupakan sebuah proses memanusiakan manusia, dengan adanya sistem pendidikan diharapkan mampu mengangkat derajat hidup menuju perubahan yang lebih baik (Sugiarta, 2019). Selain hal tersebut, Ki Hadjar Dewantara memiliki dua pandangan tentang pendidikan. pertama, tri pusat pendidikan, yang mengatakan bahwa pendidikan yang diterima oleh peserta didik terjadi dalam tiga ruang lingkup, yakni: lingkungan keluarga, lingkungan perguruan, dan lingkungan masyarakat. Ketiga, lingkungan tersebut memiliki pengaruh edukatif dalam pembentukan kepribadian peserta didik. Kedua, sistem among, yaitu suatu sistem pendidikan yang berjiwa kekeluargaan bersendikan kodrat alam dan kemerdekaan. Sistem among menurut cara berlakunya disebut sistem "Tut Wuri Handayani" (Widodo, 2017). Tri pusat pendidikan tersebut akan melahirkan calon pemimpin bangsa yang berkarakter ing ngarsa sung tuladha (dimuka memberi contoh), ing madya mangun karsa (di tengah membangun cita-cita), dan tut wuri handayani (mengikuti dan mendukungnya). Ki Hadjar Dewantara mengidealkan pemimpin yang masa depan memiliki karakter yang tangguh dan disiplin terhadap dirinya serta bermanfaat bagi lingkungan di sekitarnya. Pemimpin dengan tiga karakter tersebut, jika menjadi pemimpin masa depan akan memegang teguh amanahnya dan tidak menyalahgunakan kekuasaan. Hal tersebut dibutuhkan oleh bangsa Indonesia karena selama ini banyak pemimpin di negeri ini yang menyalahgunakan kekuasaan untuk kepentingan pribadi maupun kelompok. Ki Hadjar Dewantara memiliki konsep tentang pendidikan yang didasarkan pada asas kemerdekaan yang memiliki arti bahwa manusia diberi kebebasan dari Tuhan yang Maha Esa untuk mengatur kehidupannya dengan tetap sejalan dengan aturan yang ada di masyarakat. Tujuan pendidikan adalah kesempurnaan hidup manusia sehingga dapat memenuhi segala keperluan lahir dan batin yang diperoleh dari kodrat alam (Dewantara, 
2009). Maksud pendidikan menurut Ki Hadjar Dewantara, yaitu mendapatkan kemajuan lahir dan batin. Pertama, tentang tujuan pendidikan disebutkan tentang kepuasan atau ketentraman lahir dan batin, atau juga dapat diterjemahkan sebagai bahagia, atau rahayu, yaitu kondisi seseorang dalam keadaan senang dalam hidup batin, sehingga dapat dipahami jika pendidikan merupakan cara untuk mendapatkan kemerdekaan jiwa (Dewantara, 2009). Menurut Ki Hadjar Dewantara, pendidikan merupakan salah satu usaha pokok untuk memberikan nilai-nilai kebatinan yang ada dalam hidup rakyat yang berkebudayaan kepada tiap-tiap turunan baru (penyerahan kultur), tidak hanya berupa "pemeliharaan" akan tetapi juga dengan maksud "memajukan" serta "memperkembangkan" kebudayaan, menuju ke arah keseluruhan hidup kemanusiaan (Dewantara, 2011). Kebudayaan yang dimaksud adalah kebudayaan bangsa sendiri mulai dari Taman Indria, anak-anak diajarkan membuat pekerjaan tangan, misalnya: topi (makuto), wayang, bungkus ketupat, atau barangbarang hiasan dengan bahan dari rumput atau lidi, bunga dan sebagainya. Hal ini dimaksudkan agar anak jangan sampai hidup terpisah dengan masyarakatnya (Dewantara, 2011). Sejalan dengan hal tersebut, Ki Hadjar Dewantara juga mengungkapkan mengenai pengertian pendidikan yang umumnya berarti daya upaya untuk memajukan bertumbuhnya budi pekerti (kekuatan batin dan karakter), pikiran (intellect), dan tubuh anak; dalam pengertian Taman Siswa tidak boleh dipisah- pisahkan bagianbagian itu agar kita dapat memajukan kesempurnaan hidup, yakni kehidupan dan penghidupan anakanak yang kita didik selaras dengan dunianya" (Taman Siswa dalam Mudana, 2019). Pendidikan yang dimaksud oleh Ki Hadjar Dewantara, yakni mempertimbangkan keseimbangan cipta, rasa, dan karsa tidak hanya sebagai proses transfer ilmu pengetahuan namun sekaligus proses transformasi nilai. Sehingga dengan kata lain, pendidikan diharapkan mampu membentuk karakater manusia menjadi manusia yang seutuhnya. Dalam hal lain karakter memiliki istilah sederhana dalam pendidikan budi pekerti, kata karakter berasal dari bahasa inggris character yang artinya watak. Ki Hadjar Dewantara telah jauh berpikir dalam masalah pendidikan karakter, mengasah kecerdasan budi sungguh baik karena dapat membangun budi pekerti yang baik dan kokoh, hingga dapat mewujudkan kepribadianm (persoonlijkhheid) dan karakter (jiwa yang berasas hukum kebatinan). Jika itu terjadi, orang akan senantiasa dapat mengalahkan nafsu dan tabiat-tabiatnya yang asli, seperti bengis, murka, pemarah, kikir, keras, dan lain-lain (Taman Siswa.1977 dalam Mudana, 2019). Ki Hadjar Dewantara memiliki strategi pengembangan pendidikan diantaranya pertama, pandangan mengenai jiwa merdeka yang harus ditanamkan pada generasi penerus karena hanya mereka yang berjiwa merdeka yang dapat melanjutkan perjuang dan mempertahankan kemerdekaan bangsa Indonesia sehingga dibutuhkan pendidikan nasional dan pendidikan merdeka pada anak-anak untuk memperjuangkan kemerdekaan nasional, yaitu merdeka secara lahir dan batin (Tauchid, 2011). Dapat dipahami bahwa merdeka merupakan berarati sanggup dan kuat untuk berdiri sendiri. Kedua, pendidikan merupakan suatu usaha untuk memberikan segala kebatinan, yang ada dalam hidup rakyat yang berkebudayaan kepada setiap pencerahan kultur, tidak hanya pemeliharaan akan tetapi juga memajukan serta mengembangkan kebudayaan menuju arah keluhuran hidup kemanusiaan (Dewantara, 2009). Ketiga, pendidikan merupakan sarana dalam mencapai pembaharuan, sehingga harus dipahami bahwa segala kepentingan anak didik mengenai kepentingan pribadi maupun masyarakat jangan sampai meninggalkan kepentingan yang berhubungan dengan kodrat keadaan alam maupun zaman. Dalam melaksanakan pengajaran yang luhur adalah yang terdapat kodrat alam di dalamnya, untuk mengetahui kodrat alam itu seseorang perlu memiliki kebersihan budi, yaitu sikap yang terdapat pada berpikir, halusnya rasa, dan kekuatan kemauan atau keseimbangan antara cipta rasa, dan karsa (Ainia. 2020 : 97)

\section{Perjuangan Ki Hadjar Dewantara Dalam Memajukan Pendidikan Nasional}

Sebelum memasuki lapangan pendidikan terlebih dahulu beliau berjuang dalam lapangan politik. Bersama-sama dengan Dr. Dowes dekker dan Dr. Cipto Mangungunkusumo, beliau mendirikan suatu partai politik yang bernama Indisce Partij (IP) yang bersifat revolusioner. Pada 
tahun 1912 bersama Dr. Cipto beliau mendirikan "Komite Bumiputera" yang bertujuan untuk memprotes perayaan peringatan 100 tahun kemerdekaan Nedherland dari penindasan Napoleon Bonaparte Raja Prancis. Dalam perayaan ini masyarakat nusantara di paksa untuk ikut merayakan kemerdekaan tersebut dan di haruskan juga untuk mengumpulkan uang untuk pembiayaan perayaan. Untuk memprotes perayaan ini beliau mengeluarkan brosur pertama yang berjudul "Als i keens Nederlander was" (seandainya aku seorang Belanda) yang berisi pernyataan tidak selayaknya bangsa Indonesia yang di tindas oleh belanda ikut merayakan kemerdekaan bangsa yang menindas tersebut. Karena di angap berbahaya akhirnya beliau di buang ke Bangka dan selanjutnya di buang ke Belanda setelah 4 tahun barulah beliau di pulangkan kembali ke Indonesia. Sekembalinya ke tanah air beliau melanjutkan aksi politiknya pada tahun 1919 beliau menjadi Sekertaris Nasional Indiche Partij (NIP) yang di organisir oleh Dr. Cipto dan menjadi direktur ke -3 majalah NIP yaitu "De Beweging, persatuan India dan pengugah". Namun karena di sebabkan oleh semakin kejamnya tindakan pemerintah belanda terhadap pergerakan rakyat dan agar pekerjaan untuk kepentingan bangsa dapat bermanfaat, maka beliau meninggalkan lapangan politik dan memasuki lapangan pendidikan untuk memperjuangkan kemerdekaan rakyat mulai tahun 1921 beliau memulai dari sekolah "Adidarma" yang didirikan oleh kakaknya R.M. Suryopranoto. (Djumhur, 1976; 171)

Tanggal 3 Juli 1922 babak baru perjuangan Ki Hadjar Dewantara dalam bidang pendidikan di mulai yaitu dengan mendirikan Taman Siswa yang mula-mula bernama "National Onderwijs Instituut Taman Siswa” yang pertama di Jogjakarta, sekolah ini kelak di ubah menjadi Perguruan Kebangsaan Taman Siswa" sekolah ini awalnya di peruntukan hanya untuk taman anak dan kursus guru.

\section{Cita-Cita Pendidikan Ki Hadjar Dewantara}

Ki Hadjar Dewantara berpendapat bahwa pendidikan itu termasuk (pengajaran) bagi tiap bangsa termasuk pemeliharaan guna mengembangkan generasi penerus bangsa, agar dapat berkembang dengan sehat lahir batin. Untuk itu manusia-Individu harus di kembangkan jiwa raganya dengan memanfaatkan segala upaya dan media pendidikan yang berdasarkan adat istiadat rakyat.

Pendidikan yang kita terima dari bangsa barat tidak sesuai dengan tuntutan di atas dikarenakan pendidikan barat tidak sesuai dengan kebutuhan bangsa Indonesia. Penndidikan colonial hanya untuk kepentingan colonial saja. Isinya tidak disesuaikan dengan jiwa raga bangsa. Ki Hadjar Dewantara mengangap bahwa pendidikan colonial tidak dapat mengadaakan peri kehidupan bersama, sehingga selalu kita bergantung pada kaum penjajah. Pendidikaan colonial itu tidak dapat menjadikan kita manusia merdeka. Keadaan ini tidak akan lenyap jika hanya di lawan dengan pergerakan politik saja. Tetapi juga harus di imbangi juga dengan gerakan pendidikan yang akan menyebarkan benih hidup merdeka di kalangan rakyat dengan jalan pengajaran dan pendidikan nasional. Dengan pendidikan nasional di maksudkannya; suatu system pendidikan baru yang berdasarkan atas kebudayaan kita sendiri mengutamakan kepentingan masyarakat. Pendidikan yang mengutamakan "intelektualisme" harus di jauhi dan di ganti dengan system mengajar yang di namai system Among yang menyokong kodrat alam anak-anak didik bukan dengan” perintah paksaan” tetapi dengan "tuntunan" agar berkembang hidup lahir batin anak menurut kodratnya sendiri dengan subur dan selamat. System among ini mengemukakan dua dasar yaitu: 1). kemerdekaan sebagai syarat untuk menghidupkan dan mengerakan kekuatan lahir dan batin hingga dapay hidup merdeka (dapat berdiri sendiri) 2).kodrat alam sebagai syarat untuk menghidupkan dan mencapai kemajuan dengan secepat-cepatnya dan sebaik-baiknya.

Panca darma merupakan dasar segala usaha taman siswa baik dalam bentuk pendidikan dan pengajaran maupun yang berhubungan dengan organisasi ataupun adat istiadat dalam hidup ketaman siswaan. Terdapat lima syarat mutlak yang terkandung dalam panca darma yaitu: 1). Kemerdekaan, 2). Kodrat Alam, 3). Kebudayaan, 4). Kebangsaan, 5). Kemanusiaan 
Usaha-usaha yang di lakukan oleh Ki Hadjar Dewantara dalam melaksanakan cita-cita pendidkannya yaitu dengan mendirikan Perguruan Kebangsaan "Taman Siswa” pada tanggal 3 Juli 1922 di Jogyakarta. Pada sekolah-sekolah Taman Siswa diadakan Pembaagian-Pembagian Sebagai Berikut; 1). Taman Indriya (Taman Kanak-Kanak Taman Siswa) bagi anak-anak yang berumur 5-6 Tahun. 2). Taman Anak (kelas I-III) bagi anak-anak berumur 6-7 Tahun - 9-10. 3). Taman Muda (IVVI) bagi anak-anak yang berumur 10-11 tahun - 12-13 tahun. 4). Taman Dewasa (SMP). 5). Taman Madya (SMA). 6). Taman Guru

Isi Rencana Pembelajaran Taman Siswa menunjukan sifat kultur nasional. Tiap-tiap mata pelajaran di berikan sebagai bagian dari peradaban bangsa dan di sesuaikan dengan perkembangan jaman. Pemuda-pemuda tidak boleh lagi terikat oleh ikatan tradisi dan konvensi-konvensi yang dapat menghambat pesatnya kemajuan bangsa. Segala pelajaran harus dapat membangkitkan perasaan cinta kepada tanah air dan bangsa di dalamnya memuat lagu-lagu nasional, cerita tentang kepahlawanan bangsa, keindahan alam tanah air yang di perkenalkaan melalui darma wisata dll. Selain pendidikan kognitif juga terdapat pendidikan kesusilaan serta pendidikan kebudayaan yang bersifat kebangsaan. Murid-murid mempelajari kesenian diantaranya pelajaran melukis, music, menari, gamelan, sesuai dengan minat masing-msing. Menurut Ki Hadjar Dewantara kesenian kebangsaan dapat di ajarkan dalam kelas atau di luar kelas untuk meningkatkan kesusilaan dan meneguhkan semangat kebangsaan. Bahasa Indonesia sebagai bahasa persatuan dan bahasa pengantar dijadikan sebagai mata pelajaran wajid dan bahasa daerah di ajarkan sebagai mata pelajaran di daerh masing-masing. Pelajaran bahasa asing di ajarkan untuk menambah pengetahuan siswa tentang hubungan antar Negara. Mata pelajaran Sejarah dan Ilmu bumi menjadi salah satu mata pelajaran penting yang dapay membangkitkan rasa kebangsaan (Djumhur, $1976 ; 180$ )

Taman Siswa selalu mengutamakan semboyang-semboyang serta perlambangan dalam pemgajaran dan pendidikan. Hal ini di anggap perlu untuk menyempurnakan perkembangannkepribadian anak-anak, bukan hanya pikirannya juga perasaannya. Semboyansemboyan dan perlambangaan di tuangkan dalam bentuk sastra dan juga lukisan maupun wujud keesenian lainnya sehingga peserta didik dapat mudah mengingatnya. Semboyan dan perlambangan tersebut diantaranya : 1).Lawan Sastra Ngesti Mulia, Inilah semboyan taman siswa yang pertama menjelaskan maksud berdirinya Taman Siswa pada tahun 1922 yang di artikan Kecerdasan Jiwa Menuju ke Arah Kesejahteraan. 2). Suci Tata Ngesti Tunggal, Menjelaskan terjadinya persatuan Taman Siswa pada tahun 1923 yang artinya: dengan kesucian hati mengejar kesempurnaan. Dapat juga di artikan; Kesucian dan Ketertiban menuju kesatuan. 3). Tut Wuri Handayani, Artinya; mengikuti di belakang sambil memberi pengaruh. Di maksudkan jangan menarik-narik anak dari depan biarkanlah mereka mencari jalan sendiri. Pamong boleh turun tangan apabila anak-anak salah jalan. Kemajuan yang sejati hanya dapat dengan perkembangan kodrati, tidak perlu mempergunakan perintah, paksaan dan hukuman. 4). Kita Berhamba kepada Sang Anak, Maksudnya: pendidikan dengan ikhlas dan tidak terikat oleh apapun juga mendekati si terdidik untuk mengorbankan diri kepadanya. Jadi bukan murid untuk guru tetapi sebaliknya. 5). Rawe-rawe rantas, malang-malang putung. Segalanya yang menghalangi akan hancur. Semboyang ini dipakai untuk memperteguh kemauan.i.

\section{KESIMPULAN}

Pandangan Ki Hadjar Dewantara Tentang Pendidikan dapat di lihat dari tekad beliau untuk meluaskan semangat tentang pendidikan kepada generasi muda. Dalam pandangan beliau upaya untuk mendidik kaum muda merupakan syarat utama dalam membebaskan diri dari jeratan penjajah. Pendidikan yang mendasarkan kebudayaan nasional dapat menghindarkan dari kebodohan. Pendidikan yang ada pada masa kolonial tidak mencerdaskan, melainkan mendidik manusia untuk tergantung pada nasib dan bersikap pasif. Keinginan untuk merdeka harus dimulai dengan 
mempersiapkan kaum bumi putra yang bebas, mandiri, dan pekerja keras. Sehingga generasi muda harus dipersiapkan agar kelak menjadi bangsa yang mandiiri, sadar akan kemerdekaan, sehingga kemerdekaan itu dimiliki oleh orang yang terdidik dan memiliki jiwa yang merdeka. Untuk mewujudkan tekar dan cita-cita tersebut Tanggal 3 Juli 1922 babak baru perjuangan Ki Hadjar Dewantara dalam bidang pendidikan di mulai yaitu dengan mendirikan Taman Siswa yang mulamula bernama "National Onderwijs Instituut Taman Siswa" yang pertama di Jogjakarta, sekolah ini kelak di ubah menjadi " Perguruan Kebangsaan Taman Siswa”sekolah ini awalnya di peruntukan hanya untuk taman anak dan kursus guru. Konsep pendidikan ideal menurut K Ki Hadjar Dewantara dapat di lihat dari system pendidikan Taman Siswa selalu mengutamakan semboyang-semboyang serta perlambangan dalam pemgajaran dan pendidikan. Hal ini di anggap perlu untuk menyempurnakan perkembangannkepribadian anak-anak, bukan hanya pikirannya juga perasaannya. Semboyansemboyan dan perlambangaan di tuangkan dalam bentuk sastra dan juga lukisan maupun wujud keesenian lainnya sehingga peserta didik dapat mudah mengingatnya. Semboyan dan perlambangan tersebut diantaranya : 1).Lawan Sastra Ngesti Mulia, Inilah semboyan taman siswa yang pertama menjelaskan maksud berdirinya Taman Siswa pada tahun 1922 yang di artikan Kecerdasan Jiwa Menuju ke Arah Kesejahteraan.2). Suci Tata Ngesti Tunggal, Menjelaskan terjadinya persatuan Taman Siswa pada tahun 1923 yang artinya: dengan kesucian hati mengejar kesempurnaan. Dapat juga di artikan; Kesucian dan Ketertiban menuju kesatuan. 3). Tut Wuri Handayani, Artinya; mengikuti di belakang sambil memberi pengaruh. Di maksudkan jangan menarik-narik anak dari depan biarkanlah mereka mencari jalan sendiri. Pamong boleh turun tangan apabila anak-anak salah jalan. Kemajuan yang sejati hanya dapat dengan perkembangan kodrati, tidak perlu mempergunakan perintah, paksaan dan hukuman. 4). Kita Berhamba kepada Sang Anak, Maksudnya: pendidikan dengan ikhlas dan tidak terikat oleh apapun juga mendekati si terdidik untuk mengorbankan diri kepadanya. Jadi bukan murid untuk guru tetapi sebaliknya.5). Rawe-rawe rantas, malang-malang putung, Segalanya yang menghalangi akan hancur. Semboyang ini dipakai untuk memperteguh kemauan.

\section{Daftar Pustaka}

A Ainia, Dela Khoirul. (2020). Merdeka Belajar Dalam Pandangan Ki Hadjar Dewantara dan Relevansinya bagi Pengembangan Pendidikan Karakter. Jurnal Filsafat Indonesia, Vol 3 No 3 Tahun 2020

Dewantara, Ki Hadjar. (2009). Menuju Manusia Merdeka. Yogyakarta: Leutika.

Dewantara, Ki Hadjar. (2011). Bagian Pertama Pendidikan.Yogyakarta: Majelis Luhur Pesatuan.

Departemen Pendidikan Nasional (2004). Kurikulum 2004. Standard Kompetensi Taman Kanakkanak dan Raudatul Athfal. Jakarta: Direktorat Jenderal Pendidikan TK dan SD.

Djumhur., Danasuparta. (1976). Sejarah Pendidikan. Bandung : CV Ilmu Bandung

Departemen Pendidikan Nasional (2004). Kurikulum 2004. Standard Kompetensi Taman Kanakkanak dan Raudatul Athfal. Jakarta: Direktorat Jenderal Pendidikan TK dan SD.

Haidar Musyafa. (2015). "Sang Guru”. Novel Ki Hajar Dewantara, Kehidupan, Pemikiran, Perjuangan Pendirian Taman Siswa, 1889-1959.Yogyakarta: M. Kahfi.

Marisyah,Ab., Firman, Rusdinal. (2019). Pemikiran Ki Hadjar Dewantara Tentang Pendidikan. Riau : Jurnal Pendidikan Tambusai. Vol 3 No 6 Tahun 2019 h. 1517.

Marihandono, Djoko. (2017). Rawe-Rawe Rantas Malang-Malang Putung: Jejak Soewardi Soerjaningrat Hingga Pembuangan. Jakarta: Makalah Seminar "Perjuangan Ki Hadjar Dewantara dari Politik ke Pendidikan.

Mudana, I Gusti Agung Made Gede, Membangun Karakter dalam Perspektif Filsafat Pendidikan Ki Hadjar Dewantara. Jurnal Filsafat Indonesia Vol. 2 No. 22019 h.75-81.

Muhadjir,1991, Metodologi Penelitian Kualitatif Edisi 4 
Sugiarta, I.M.,Mardana.I.B.P, Adiarta, A.,\&Artanayasa, I.W. (2019). Filsafat Pendidikan Ki Hadjar Dewantara (Tokoh Timur). Jurnal Filsafat Indonesia. Vol 2 No 3Tahun 2019 h.124-136.

Tauchid, Muchammad. (2011). Perjuangan dan Ajaran Hidup Ki Hadjar Dewantara. Yogyakarta: Majelis Luhur Tamansiswa Yogyakarta.

Kuntoro, Sodiq A. 1988. "Hubungan antara beberapa Faktor Guru, Strategi, Intruksional, dan Hasil Belajar Siswa taman Kanak-kanak”. Disertasi S3. Fakultas Pasca Sarjana Institut Keguruan dan Ilmu Pendidikan Jakarta. Maret 1988.

Widodo, Bambang. (2017). Biografi: Dari Suwardi Suryaningrat Sampai Ki Hadjar Dewantara. Jakarta: Makalah Seminar "Perjuangan Ki Hadjar Dewantara dari Politik ke Pendidikansriyadin. (2017). Panduan Penulisan Jurnal STKIP Taman Siswa Bima. Bima: LPPM Taman Siswa Bima. 